[75]

\title{
The Influence of Brand Equity Elements on Purchase Decision and Its Imlication on Customer Loyalty
}

\author{
Lingga Binangkitsari and Sulistiono \\ Sekolah Tinggi Ilmu Ekonomi Kesatuan \\ digmakclass@gmail.com
}

\begin{abstract}
This research aims to determine how the influence of brand equity elements (brand awareness, brand association, perceived quality, and brand loyalty) to purchase decision and their impact on consumer loyalty PT. Garuda Indonesia in Bogor City. This research used exogenous variables (brand awareness, brand association, perceived quality and brand loyalty) and endogenous variables (purchase decision and costumer loyalty). The sample method that used in this research was Roscoe. With 100 respondents selected are people who have been used the inflight services of Garuda Indonesia. This research data is processed using AMOS 22 for structural equation modeling analysis. The results of this research shows that brand awareness has a positive and significant influence to purchase decision, brand association has a positive and significant impact to purchase decision, perceived quality has a positive and significant influence to purchasie decision, brand loyalty has a positive and significant influence to purchase decision, and purchase decision has a positive and significant impact on customer loyalty. Because all variables show the result of t-count or Critical Ratio (C.R.) $\geq 1.96$ or $\mathrm{p}$ value $\leq 0.05$ which means the hypothesis is accepted.
\end{abstract}

Keyword: Brand Awareness, Brand Association, Perceived Quality, Brand Loyalty, Purchase Decision, Customer Loyalty 